\title{
Potential for future growth in lamb supply from sheep and beef farming systems in Hawke's Bay, New Zealand
}

\author{
J. R. Beautrais, R.E. Vibart, A. D. Mackay and I. Vogeler \\ AgResearch - Grasslands Research Centre, Private Bag 11008, Palmerston North 4442, New Zealand. \\ Email: josef.beautrais@agresearch.co.nz
}

\begin{abstract}
The potential for expanding irrigation on the Ruataniwha Plains (Hawke's Bay, New Zealand) through proposed in-river water storage creates new land use options, including lamb finishing. It has been estimated that 500,000 additional lambs could be finished each year from 10,000 of the 20,000+ ha within the proposed irrigation scheme. Sheep and beef farming is the predominant land use, covering 785,000 ha or $60 \%$ of the Hawke's Bay Region, which has a predominantly summer-dry environment. The majority of sheep and beef farms are found in hill and steep-land, landscapes some vulnerable to landslides and associated soil erosion and sediment loss during rain storm events.
\end{abstract}

There are calls to transition land use on the most vulnerable land to landslides to protective woody vegetation, including production forestry or space planted trees. Using a novel approach of linking spatial land resource information to regional economic data, we modelled lamb production under scenarios of land use change, hierarchically at farm and regional scales. Our results suggest that increases in lamb production on the high-production capability land on-farm, achievable through increases in efficiency and intensification, would offset reductions in production due to tree planting. Further, the additional store lamb demand for finishing created by the proposed water storage project, through the development of 10,000 ha of intensive lamb finishing, could be met by ongoing productivity gains from sheep and beef operations in hill land. Our spatially linked approach to analysis contrasts against a status-quo of regional-scale averages. This offers industry and policy-makers greater confidence in appraising investment options and policy options for managing land use and land use change, respectively.

Keywords: $\quad$ Land use change, irrigation, Ruataniwha Water Storage scheme 
Beautrais et al., Potential for future growth in lamb supply from sheep and beef farming systems in Hawke's Bay, New Zealand

\section{INTRODUCTION}

The Hawke's Bay region is located on the east coast of the New Zealand's North Island. The region is marked by contrasts, comprising large areas of flat, fertile alluvial plains and basins, with areas of steep hill country in the West and South-East. This strong contrast of terrain results in contrasting land uses. The hill country is mostly used for sheep and beef production. On the lowlands there are large areas of intensive pastoral farming, along with orchards and vineyards. The region lies on the leeward side of the North Island's axial mountain ranges, and has a predominantly Mediterranean climate. However, the region commonly experiences climatic extremes including frequent summer droughts, and high rainfall storm events. Parts of the region's hill country suffers from erosion, primarily through landslides, owing to a combination of steep topography, soft sedimentary geology, exposure to extreme spasmodic climatic events, and much-reduced vegetation cover compared to the conditions under which the landscapes were formed. The Hawke's Bay Regional Council (HBRC) has launched an initiative to encourage land use change on the region's most erosion-prone pastoral land to woody vegetation, including plantation pine, and spaced planted trees. These climatic extremes pose major challenges to agriculture, by virtue of both their magnitude and, particularly, the inter-annual uncertainty they impose. The region is predicted to become drier over the coming decades under anticipated climate change (Lieffering et al., 2012) which is likely to exacerbate existing water scarcity.

The predominant land use in the region comprises dryland pastoral agriculture, predominantly mixed livestock sheep and beef farming (referred to as sheep and beef), with limited areas of intensified irrigated agriculture (Gordon, 2013). Currently, meat is the primary output, with wool production being of lesser economic importance in the region $(\mathrm{B}+\mathrm{LNZ}, 2013)$. Pasture makes up the majority of livestock feed. Farms can be broadly divided between breeding and finishing operations. Typically, lambs are bred in relatively extensive systems located mostly on hill country, with a proportion sold to more intensive finishing operations located in neighbouring regions (e.g. Manawatu), where water availability is more reliable for pasture production and livestock finishing.

The HBRC has proposed an in-river water storage scheme to provide water for irrigation on the Ruataniwha Plains. Current irrigation on the Ruataniwha relies on a ground- and surface-water resource, which is over-allocated. The proposed scheme aims to reduce the uncertainty of supply and ecological impacts of the current situation, as well as increasing the overall supply of irrigation water. Under the scheme, water would be stored in a dam on the Makaroro River, and released as needed to feed downstream abstraction intakes. Water capture in the dam would occur mostly in the winter, with abstraction occurring through spring and summer. Current land uses on the Ruataniwha associated with water include dairy, sheep and beef and horticulture.

Much of the dialogue on the potential economic benefits of the scheme has so far focussed on improved agricultural performance within the irrigated zone in isolation. A feasibility study by McFarlane and associates examined land use change to dairy, cropping, process vegetables and horticulture as part of the initial feasibility study for the scheme. Little attention has been paid to potential integration of regional supply chains.

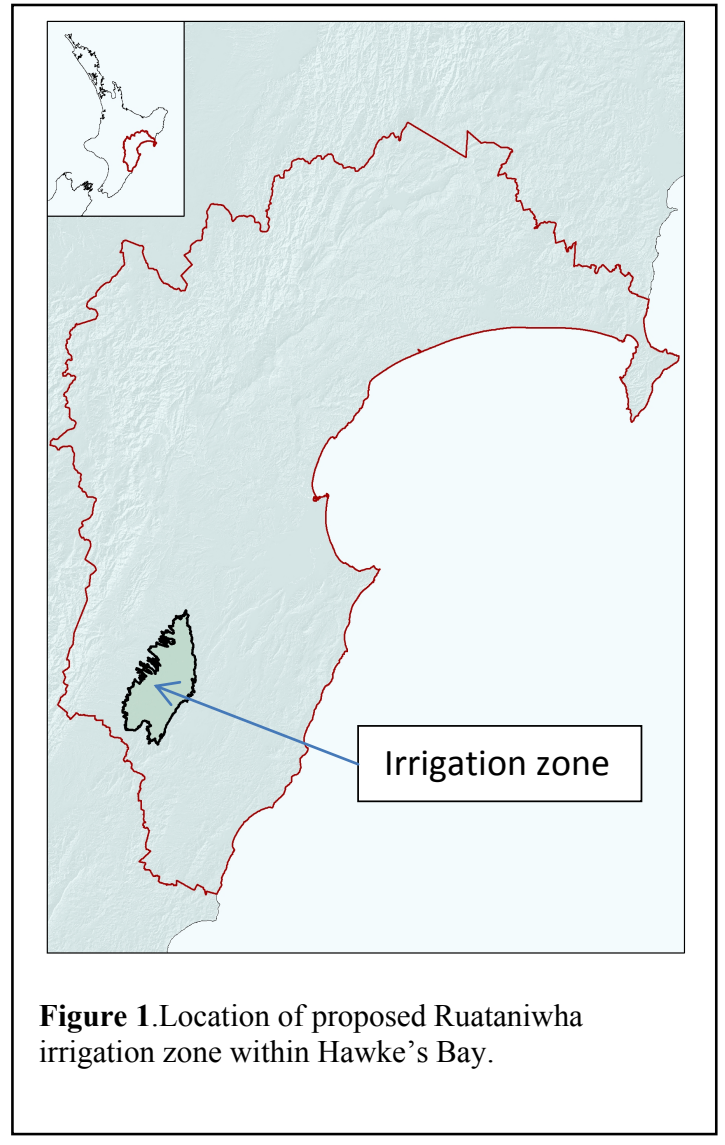


Beautrais et al., Potential for future growth in lamb supply from sheep and beef farming systems in Hawke's Bay, New Zealand

This study investigates a methodology for exploring the potential economic benefits in the Hawkes Bay from the in-river water storage project from linking lamb rearing in the hill country with intensive lamb finishing on the Ruataniwha Plains under irrigation.

We present plausible predictions of changes in lamb supply from likely scenarios of land use change over the coming 20 years, by linking farm-scale modelling to spatial and regional economic databases.

\section{METHODS}

\subsection{Mapping of representative sheep and beef farming systems in Hawke's Bay}

Sheep and beef farms in Hawke's Bay were identified from AgriBase ${ }^{\circledR}$ (herein AgriBase; AsureQuality 2011). AgriBase is a spatial database of national coverage which contains farm information including enterprise type. Representative farming systems for Hawke's Bay were sourced from Beef and Lamb New Zealand (B+LNZ, 2013) and included Class 3 (North Island hard hill country), Class 4 (North Island hill country) and Class 5 (North Island intensive finishing) farms. Farm Classes and an estimation of the number of farms represented by each Class in New Zealand are briefly described, as follows: a) Class 3 farms (representing over 1100 farms throughout New Zealand) are located on steep hill country with a livestock carrying capacity of 6 to 10 stock units SU/ha and a high proportion of livestock sold in store condition; b) Class 4 farms (representing over 4000 farms) are located on more productive easier hill country than Class 3 , a greater livestock carrying capacity of 7 to $13 \mathrm{SU} /$ ha and a greater proportion of lambs finished in prime condition; and c) Class 5 farms (representing over 1500) are often located in gentler slopes with a greater livestock carrying capacity ( 8 to $15 \mathrm{SU} / \mathrm{ha}$ ) and higher proportion of lambs finished to slaughter than Class 3 . A high proportion of livestock are also purchased.

To group the region's sheep and beef farms into B+LNZ Classes, a GIS analysis was performed after first developing size and land use capability (LUC) attribute-based definitions for the three B+LNZ farm Classes (Table 1). The LUC (Lynn et al., 2009) data was sourced from the New Zealand Land Resource Inventory (NZLRI) spatial database (Landcare Research NZ Ltd).

The attributes were assigned to each of the sheep and beef farms in the region stored in the AgriBase spatial database to provide a spatially explicit biophysical link between the farms in the region, with the three B+LNZ farm Classes, which was used to explore on-farm performance through modelling. The choice of the two attributes to identify Class 3 and Class 5, with Class 4 by difference, was based primarily on the descriptors used by $\mathrm{B}+\mathrm{LNZ}$ to describe these three farm Classes. The initial analysis was informally validated by visual inspection of mapped farm Classes (Figure 2) linked with knowledge of farms within each Class.
Table 1. Assumptions used in the modelling of B+LNZ farm Class areas in Hawke's Bay

\begin{tabular}{llll}
\hline \multirow{2}{*}{ Class } & Description & \multicolumn{2}{l}{ Attribute Criteria } \\
\cline { 3 - 4 } & & 6 to 8 & Size (ha) \\
\hline 3 & $\begin{array}{l}\text { Hard Hill } \\
\text { Country }\end{array}$ & $>80$ & $>500$ \\
4 & Hill Country & $\geq 40$ & $\begin{array}{l}\leq 500 \\
\text { if } \% \text { LUC 6-8 }>80\end{array}$ \\
5 & $\begin{array}{l}\text { Intensive } \\
\text { Finishing }\end{array}$ & $<40$ & (No size criteria) \\
\hline
\end{tabular}


Beautrais et al., Potential for future growth in lamb supply from sheep and beef farming systems in Hawke's Bay, New Zealand

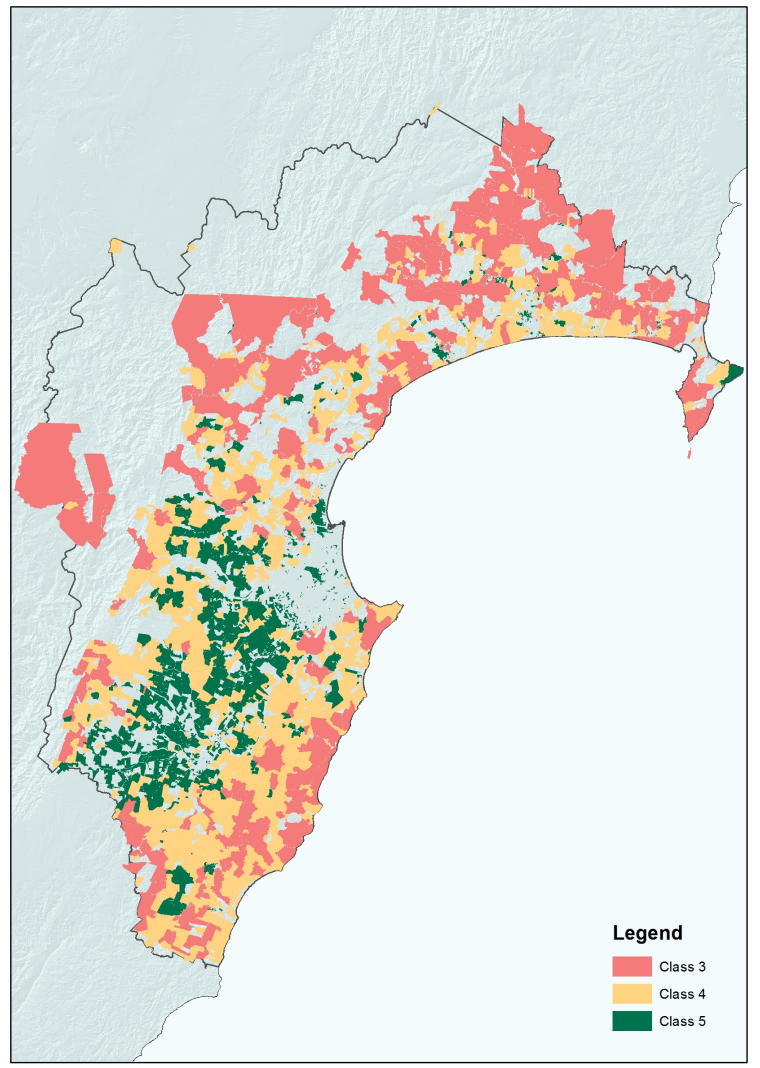

Figure 2. Distribution of farm Classes across Hawke's Bay Region.

\subsection{Calculation of lamb numbers}

Once the farms were grouped into the three Classes, lamb production was calculated using a series of parameters assigned to each Class: proportion of total area farmed, stocking rate, proportion of sheep relative to total livestock and lambing percentage. These were then multiplied by the number of hectares in each farm Class.

Table 2. Land area, proportion farmed and livestock policies for each B+LNZ farm Class in Hawke's Bay.

\begin{tabular}{cccccccc}
\hline $\begin{array}{c}\text { B+LNZ } \\
\text { Class }\end{array}$ & Area & $\begin{array}{c}\text { Proportion } \\
\text { Farmed }\end{array}$ & $\begin{array}{c}\text { Stock Rate } \\
\text { (SU/ha) }\end{array}$ & $\begin{array}{c}\text { Proportion } \\
\text { Sheep }\end{array}$ & Number Sheep & Lambing (\%) & $\begin{array}{c}\text { Number } \\
\text { Lambs }\end{array}$ \\
\hline 3 & 365,226 & 0.75 & 9.2 & 0.65 & $1,638,039$ & 1.19 & $1,949,266$ \\
4 & 289,256 & 0.85 & 10.8 & 0.60 & $1,593,223$ & 1.20 & $1,911,868$ \\
5 & 125,546 & 0.91 & 12.3 & 0.60 & 843,145 & 1.40 & $1,180,403$ \\
\hline
\end{tabular}

The proportion farmed refers to the area of a farm under pastoral production. Farms often comprise multiple land uses, with areas of plantation pine, native vegetation and riparian common. Figures for the proportion farmed were estimated from B+LNZ data and cross-validated against spatial land cover data from LCDB3 (Landcare Research NZ Ltd). Stocking rate, the proportion of livestock as sheep, and lambing percentage were based on data from B+LNZ (2013). Data were validated by local expert opinion (Ian Millner (HBRC), personal communication). The calculated lamb numbers were compared with estimates obtained through discussions with industry. 
Beautrais et al., Potential for future growth in lamb supply from sheep and beef farming systems in Hawke's Bay, New Zealand

To check on the robustness of the calculations total ewe and lamb numbers for the Central Hawke's Bay (Waipawa and Waipukurau counties) estimated by the methodology described above were compared with the ewe and lamb numbers for the Central Hawke's Bay supplied by B+LNZ Economic Service. Average sheep numbers for the 5 year period 2007-2012 supplied by B+LNZ Economic Service were 1,419,800. Our model estimate was $1.7 \%$ higher, at $1,443,800$, showing very good agreement.

\subsection{Farm modelling under irrigation on the Ruataniwha Plains}

Potential increase in lamb production from the Ruataniwha plains was modelled using a multi-step process. Expected increases in pasture production due to irrigation were modelled using a deterministic Agricultural Production Systems Simulator model, APSIM (McCown et al., 1996). The resulting pasture production and pasture growth pattern was used in Farmax ${ }^{\circledR}$ Pro (version 6.4.6.07; herein Farmax) (White et al., 2010) to assemble a biologically feasible (i.e. matching feed supply with feed demand) lamb finishing operation on the Ruataniwha plains under irrigation.

The irrigated base-farm scenario comprised a hypothetical 404-ha farm located in the Ruataniwha plains (flat terrain) representing an intensified sheep and beef operation with similar livestock policies to those of a B+LNZ Class 5 farm (B+LNZ, 2013), but a greater proportion of purchased lambs and beef-type bull calves. Based on dry matter (DM) intake, the modelled farm comprised an animal species ratio of 76:24 (sheep:cattle) including Romney breeding ewes and Angus x Hereford breeding cows (Table 3). Up to $180 \mathrm{~kg}$ of Nitrogen (N) fertiliser was applied, along with maintenance applications of other soil nutrients (i.e. P, K, S). Excess spring pasture growth was harvested and conserved as pasture silage and fed during the autumn and winter. Additionally, Brassica fodder crops such as swedes (Brassica napobrassica) and forage rape (Brassica napus), each sown on 50 ha, provided for winter and summer grazing sources, respectively.

\subsection{Identification of land at risk of erosion}

The land at risk of erosion in the region was based on specific LUC land units identified by the Hawke's Bay Regional Council. There is a growing interest in shifting this land from pasture only, to include either conservation trees or production forestry. The implications of affecting the required land use change on farm performance was calculated by identifying the area affected on each farm and adjusting the 'proportion farmed' for each farm Class. Most of the changes were seen on Class 3 farms (Table 4).

\subsection{Integrated land use in the Hawkes Bay}

Predictions were made out 20 years to 2032 in the modelling. It was assumed that sheep fecundity will continue to increase over the period, at a rate that mirrors the increases in fertility reported over the last 20 years. Lambing percentages were also projected to increase accordingly. In addition to increased farm productivity across the three farm Classes over the next 20 years, it was assumed in 2032 that all the land at risk from erosion had been planted in protective vegetation, reducing the proportion of the whole farm in pasture. This modelling exercise was conducted to establish if the combination of ongoing productivity gains with a simultaneous reduction in the area in pasture, would impact on the potential supply of lambs for irrigated finishing farms on the Ruataniwha plains, as part of a future regional initiative. 
Beautrais et al., Potential for future growth in lamb supply from sheep and beef farming systems in Hawke's Bay, New Zealand

\section{RESULTS AND DISCUSSION}

\subsection{On farm productivity gains over the next 20 years.}

If the average producer was to lift lambing percentage over the next 20 years by $20 \%$, to $1.39 \%, 1.4 \%$ and $1.6 \%$ respectively for classes 3,4 and 5 , an extra 0.8 million lambs would be produced in the Region, given all else is kept equal. The benefit of the approach used in this study is that the productivity gains can be linked directly to each farm Class, with respective increases across Classes 3, 4 and 5 of 327,608, 318,643 and 168,624 lambs, respectively.

\subsection{Reduction in land area under sheep and beef farming}

A total area of 98,300 ha in Class 3, 4 and 5 sheep and beef farms currently in pasture was identified as at risk from erosion and targeted for land use change to reduce the risk of soil erosion (Table 4). This land is predominantly located on Class 3 Hard Hill Country farms (70\%), but appreciable areas are also located on easier Class 4 Hill Country farms (27\%), and a smaller area was identified on Class 5 Intensive Finishing farms (3\%). Affecting the necessary land use change on the 98,300 ha over the next 20 years, would reduce the livestock number and number of lambs produced by about the same amount as a $20 \%$ increase in on-farm production from the remaining land in sheep and beef. This exercise demonstrates the potential of this novel approach of linking spatial land resource information to farms systems to reflect differences in the underlying resource in the calculation of regional production and economic data. Our spatially linked approach to analysis contrasts against a status-quo of regional-scale averages. This offers industry and policy-makers greater confidence in appraising investment options and policy options for managing land use and land use change, respectively. For example, if the productivity gains in 20 years were $30 \%$ rather than $20 \%$ across each of the farm Classes and all the land at risk had been planted, the total lamb crop available in the region would be approaching 5.2 million lambs, an increase of over 300, 000 lambs on the scenario described in Table 4.

Table 4. Combined impact of the productivity gains and land use change (reduction in the proportion of land farmed) on lamb numbers

\begin{tabular}{cccccccc}
\hline $\begin{array}{c}\text { B+LNZ } \\
\text { Class }\end{array}$ & Area & $\begin{array}{c}\text { Proportion } \\
\text { Farmed }\end{array}$ & $\begin{array}{c}\text { Stock Rate } \\
\text { (SU/ha) }\end{array}$ & $\begin{array}{c}\text { Proportion } \\
\text { Sheep }\end{array}$ & Number Sheep & Lambing (\%) & $\begin{array}{c}\text { Number } \\
\text { Lambs }\end{array}$ \\
\hline 3 & 365,226 & 0.48 & 9.2 & 0.65 & $1,057,820$ & 1.39 & $1,470,369$ \\
4 & 289,256 & 0.78 & 10.8 & 0.60 & $1,459,588$ & 1.40 & $2,043,424$ \\
5 & 125,546 & 0.91 & 12.3 & 0.60 & 839,416 & 1.60 & $1,343,066$ \\
\hline
\end{tabular}

\subsection{Lamb finishing capacity under irrigation}

The current land area on the Ruataniwha plains under sheep and beef is currently 21,500 ha, of which 19,900 ha is Class 5. Under a scenario of intensifying this area through irrigation, 50 lambs could be finished per hectare every year in an intensive lamb finishing operation. If 10,000 ha were converted into intensive lamb finishing, an additional 500,000 lambs could be finished on the Ruataniwha plains. A majority of these lambs would be purchased in late November and early March, and comprise $67 \%$ of the total number of lambs finished on the irrigated system. This exercise demonstrates the merit of farm systems modelling, offering industry and policy makers further insights into investment and policy options.

\section{CONCLUSION}

Presently, estimates of how land use and policy changes will impact the region tend to rely on region-scale averages and do not take explicit account of land resource information. Our approach demonstrates the potential for utilising spatial land resource and farm data to model change in greater detail. 
Beautrais et al., Potential for future growth in lamb supply from sheep and beef farming systems in Hawke's Bay, New Zealand

The results draw attention to the opportunities to develop a more regionally integrated lamb supply chain in Hawke's Bay, explicitly linking store lamb production in hill country to intensive finishing operations in the lowlands. Currently, a proportion of the lambs weaned in the Hawke's Bay are exported to be finished in neighbouring regions such as the Manawatu. Our results show that there is enormous scope to increase local supply and capacity for lamb finishing in the Region. The value of the irrigated land is more than just extra capacity for finishing, because of the low risk, high certainty around that part of the supply chain. Lamb slaughtering and processing capacity in the region is such that it would be sufficient to complete a regionally integrated lamb supply chain.

\section{Acknowledgements}

We gratefully acknowledge funding from Rural Futures, and expert input and assistance from Ian Millner, Nathan Heath, Steven Redden, Ariana Hemara-Wahanui and Andrew Manderson.

\section{REFERENCES}

AssureQuality. (2011). AgriBase ${ }^{\circledR}$. http://www.asurequality.com/capturing-information-technology-acrossthe-supply-chain/agribase-database-for-nz-rural-properties.cfm.

B+LNZ. (2013). Beef and Lamb New Zealand, Economic Service, Sheep and Beef Farm Survey Gisborne / Hawke's Bay / Wairarapa 2012-13. Forecast and Quintile Analysis of Final 2010-11 Survey Data.

Gordon, D. (2013). Ruataniwha Groundwater Quality - State and Trends. Resource Management Group, Hawke's Bay Regional Council. http://www.hbrc.govt.nz/HBRC-Documents. Accessed $31 / 7 / 2013$.

Lieffering, M., Newton, P.C.D., Li, F.Y., Vibart, R. (2012). Chapter 4 Sheep and Beef: Hill country sheep and beef: impacts and adaptations to climate change. In: Clark, A.J.; Nottage, R.A.C. (eds). Impacts of Climate Change on Land-based Sectors and Adaptation Options. Technical Report to the Sustainable Land Management and Climate Change Adaptation Technical Working Group, pp. 145-188. Ministry for Primary Industries.

Lynn, I.H., Manderson, A.K., Page, M. J., Harmsworth, G.R., Eyles, G.O., Douglas, G.B., Mackay, A.D. and Newsome, P.J.F. (2009). Land Use Capability Survey Handbook - a New Zealand handbook for the classification of land $3^{\text {rd }}$ ed. Hamilton, AgResearch; Lincoln, Landcare Research; Lower Hutt, GNS Science. 163p.

McCown, R.L., Hammer, G.L., Hargreaves, J.N.G., Holzworth, D.P., Freebairn, D.M. (1996). APSIM: a novel software system for model development, model testing, and simulation in agricultural research. Agricultural Systems 50, 255-271.

White T.A., Snow V.O., King, W.McG. (2010). Intensification of New Zealand beef farming systems. Agricultural Systems 103, 21-35. 